\title{
Dynamics and evolution of the inverted repeat-large single copy junctions in the chloroplast genomes of monocots Rui-Jiang Wang ${ }^{\dagger 1,2}$, Chiao-Lei Cheng ${ }^{\dagger 2}$, Ching-Chun Chang ${ }^{3}$, Chun-Lin $\mathrm{Wu}^{2}$, Tian-Mu Su${ }^{2}$ and Shu-Miaw Chaw*2
}

Address: ${ }^{1}$ South China Botanical Garden, the Chinese Academy of Sciences, Guangzhou 510650, China, ${ }^{2}$ Research Center for Biodiversity, Academia Sinica, Taipei 115, Taiwan and '3nstitute of Biotechnology, National Cheng Kung University, Tainan, Taiwan

Email: Rui-Jiang Wang - rwang@graduate.hku.hk; Chiao-Lei Cheng - chiaolei@yahoo.com.tw; Ching-Chun Chang - chingcc@mail.ncku.edu.tw; Chun-Lin Wu - chun_lin0201@yahoo.com.tw; Tian-Mu Su - imidase@gmail.com; Shu-Miaw Chaw* - smchaw@sinica.edu.tw

* Corresponding author †Equal contributors

Published: 3I January 2008

BMC Evolutionary Biology 2008, 8:36 doi:10.1/86/147|-2/48-8-36
Received: 15 July 2007

Accepted: 31 January 2008

This article is available from: http://www.biomedcentral.com/|47|-2/48/8/36

(C) 2008 Wang et al; licensee BioMed Central Ltd.

This is an Open Access article distributed under the terms of the Creative Commons Attribution License (http://creativecommons.org/licenses/by/2.0), which permits unrestricted use, distribution, and reproduction in any medium, provided the original work is properly cited.

\begin{abstract}
Background: Various expansions or contractions of inverted repeats (IRs) in chloroplast genomes led to fluxes in the IR-LSC (large single copy) junctions. Previous studies revealed that some monocot IRs contain a trnH-rps 19 gene cluster, and it has been speculated that this may be an evidence of a duplication event prior to the divergence of monocot lineages. Therefore, we compared the organizations of genes flanking two IR-LSC junctions in 123 angiosperm representatives to uncover the evolutionary dynamics of IR-LSC junctions in basal angiosperms and monocots.

Results: The organizations of genes flanking IR-LSC junctions in angiosperms can be classified into three types. Generally each IR of monocots contains a trnH-rps/9 gene cluster near the IR-LSC junctions, which differs from those in non-monocot angiosperms. Moreover, IRs expanded more progressively in monocots than in non-monocot angiosperms. IR-LSC junctions commonly occurred at polyA tract or A-rich regions in angiosperms. Our RT-PCR assays indicate that in monocot $I_{A}$ the trnH-rps 19 gene cluster is regulated by two opposing promoters, $S 1 O_{A}$ and $p s b A$.

Conclusion: Two hypotheses are proposed to account for the evolution of IR expansions in monocots. Based on our observations, the inclusion of a trnH-rps 19 cluster in majority of monocot IRs could be reasonably explained by the hypothesis that a DSB event first occurred at $I R_{B}$ and led to the expansion of $I R s$ to $t r n H$, followed by a successive $D S B$ event within $\mathbb{I R}_{A}$ and lead to the expansion of IRs to $r p s / 9$ or to rp/22 so far. This implies that the duplication of $t r n H$-rps 19 gene cluster was prior to the diversification of extant monocot lineages. The duplicated $t r n H$ genes in the $\mathbb{R}_{B}$ of most monocots and non-monocot angiosperms have distinct fates, which are likely regulated by different expression levels of $S I O_{A}$ and $S I O_{B}$ promoters. Further study is needed to unravel the evolutionary significance of $I R$ expansion in more recently diverged monocots.
\end{abstract}

\section{Background}

Typically the cpDNAs of land plants contain two identical segments, the inverted repeats (IRs: $\mathrm{IR}_{\mathrm{A}}$ and $\mathrm{IR}_{\mathrm{B}}$ ), separated by two single copy (SC) sequences, the large single 
copy (LSC) region and the small single copy (SSC) region $[1,2]$. Thus four junctions, termed $\mathrm{J}_{\mathrm{LA}^{\prime}}, \mathrm{J}_{\mathrm{SA}^{\prime}} \mathrm{J}_{\mathrm{SB}}, \mathrm{J}_{\mathrm{LB}}$, are between the two IRs and the SC regions $[3,4]$. A major constraint on cpDNA is its organization into large clusters of polycistronically transcribed genes [5-7]. As a result, large structural changes in cpDNA, such as segmental duplication or deletion and mutation in gene order, are relatively rare and evolutionarily useful in making phylogenetic inferences [8].

In land plants, the sizes of rRNA gene-containing IRs are notably variable, ranging from $10 \mathrm{~kb}$ in liverworts to $20-25 \mathrm{~kb}$ in most angiosperms $[2,9,10]$, and up to $76 \mathrm{~kb}$ in Pelargonium (a eudicot) [11]. Successive IR expansions, either within angiosperms or between non-vascular plants and angiosperms, have led to floating of $\mathrm{J}_{\mathrm{LA}}$ and $\mathrm{J}_{\mathrm{LB}}$ [12] and have evolutionary significance [13-15]. Several models concerning the expansion and contraction of IR regions have been proposed to explain the possible mechanisms that result in shift of the IR-LSC junctions. For example, the unusual triple-sized expansion of the Geranium IR was hypothesized as an outcome of inversion due to recombination between homologous dispersed repeats [16]. Similarly, the at least $4 \mathrm{~kb}$ expansion of the IR in buckwheat (Fagopyrum esculentum) cpDNA was also considered to be associated with an inversion [17].

Goulding et al. [15] found that in most Nicotiana species IR regions have both expanded and contracted with slight variations in length during the evolution of the genus. The exception is $N$. acuminata, which underwent a large IR expansion of over $12 \mathrm{~kb}$. Goulding et al. [15] proposed two mechanisms of IR expansion: (i) gene conversion to account for the small IR expansion or movements in most species of the genus, and (ii) a DNA double-strand break (DSB) to explain the extensive incorporation of the LSC region into the IR of $N$. acuminata. Perry et al. [18] analyzed the endpoint sequence of a large $78 \mathrm{~kb}$ rearrangement in adzuki bean (Vigna angularis) and concluded that the unusual organization was caused by a two-step process of expansion and contraction of the IR, rather than a large inversion.

Recent phylogenetic studies using various molecular markers have yielded robust support for the hypothesis of either Amborella alone or Amborella-Nymphaeales together as the basal-most clade of angiosperms [13,19-26], and the genus Acorus has been identified as the earliest splitting lineage in monocots. However, the sister group of monocots is still unclear [26].

Monocots include about one-fourth of the world's flowering plants and represent one of the oldest angiosperm lineages [27]. However, no comparative study has been conducted to investigate the diversity and evolutionary dynamics at the IR-LSC junctions of cPDNAs in basal angiosperms and monocots as a whole. Goulding et al. [15] found that each IR in rice and maize (Poaceae) contains a fully duplicated trnH-rps19 gene cluster. Chang et al. [20] further discovered that the IRs of two other remote monocot taxa, Acorus and Orchidaceae, also include trnH and $r p s 19$ (although the 3 ' region of $r p s 19$ was truncated in Acorus), and speculated that the clustering of $r p s 19$ and trnH was probably duplicated before the diversification of extant monocot lineages.

As a result of expansion and contraction, the IRs in the cpDNA of angiosperms have been suggested as an evolutionary marker for elucidating relationships among some taxa $[14,28]$. To improve understanding of the dynamics and evolution of IR-LSC junctions from basal angiosperms to the emergence and diversification of monocots (assuming that this evolutionary course is correct), we sampled 52 key species and determined the sequences of the two regions spanning $\mathrm{J}_{\mathrm{LA}}$ (Fig. 1, between the $3^{\prime}$ end of $r p l 2$ and the $5^{\prime}$ end of $p s b \mathrm{~A}$ ) and $\mathrm{J}_{\mathrm{LB}}$ (Fig. 1, between the $3^{\prime}$ end of $r p l 2$ and the $5^{\prime}$ end of $r p l 22$ ). A total of 123 representative angiosperms, including 12 basal angiosperms, 16 magnoliids, 62 eudicots, and 33 monocots (see the additional file 1 ), were analyzed. Three types of gene arrangements flanking the $\mathrm{J}_{\mathrm{LA}}$ and $\mathrm{J}_{\mathrm{LB}}$ regions were recognized and mapped onto the angiosperm phylogeny. In order to explain this arrangements we propose two alternative hypotheses concerning the evolutionary history of the flux of IR-LSC. Furthermore, to verify the transcriptional status of the duplicated trnH-rps 19 gene cluster near the $\mathrm{IR}_{\mathrm{A}}$ junctions the activity of two operons in Asparagus densiflorus, $S 10_{A}$ and $p s b A$, was investigated.

\section{Results}

Several terms used in this section are briefly explained here. Types of IR-LSC junction are based on the organization of genes flanking $\mathrm{J}_{\mathrm{LB}}$ and $\mathrm{J}_{\mathrm{LA}}$ in angiosperms. Type $\mathrm{I}$ is found in most non-monocot angiosperm dicots. It refers to an intact $t r n H$ gene being located directly downstream of the $r p l 2$ sequence in $\mathrm{IR}_{\mathrm{A}}$ and an intact $r p s 19$ gene being located directly downstream of the $r p l 2$ sequence in $I_{B}$. No full-length $r p s 19$ or $t r n H$ sequence is present in $\mathrm{IR}_{\mathrm{A}}$ or $\mathrm{IR}_{\mathrm{B}}$ respectively. Type II refers to a partial sequence of $r p s 19$ being located directly between $r p l 2$ and $t r n H$ in $\mathrm{IR}_{\mathrm{A}}$. Type II pattern is only found in some eudicots while type III characterizes the IRs of most monocots, in which each IR contains a trnH-rps 19 cluster. The letters $\mathrm{a}_{1} \mathrm{a}^{\prime}, \mathrm{c}_{1} . .$. and $\mathrm{g}$ used in the text and in Figure 1 refer to the IR-LSC junctions found in cpDNAs of sampled angiosperms.

\section{In non-monocot angiosperms IR-LSC junctions of $I R_{B}$ are largely located between rpl 2 and rps I 9}

Figure 1 shows that the IR-LSC junctions in 90 nonmonocot angiosperms usually drift around position $\mathrm{b}$ 
A Basal Angiosperms, Magnoliids, and Eudicots

Type I

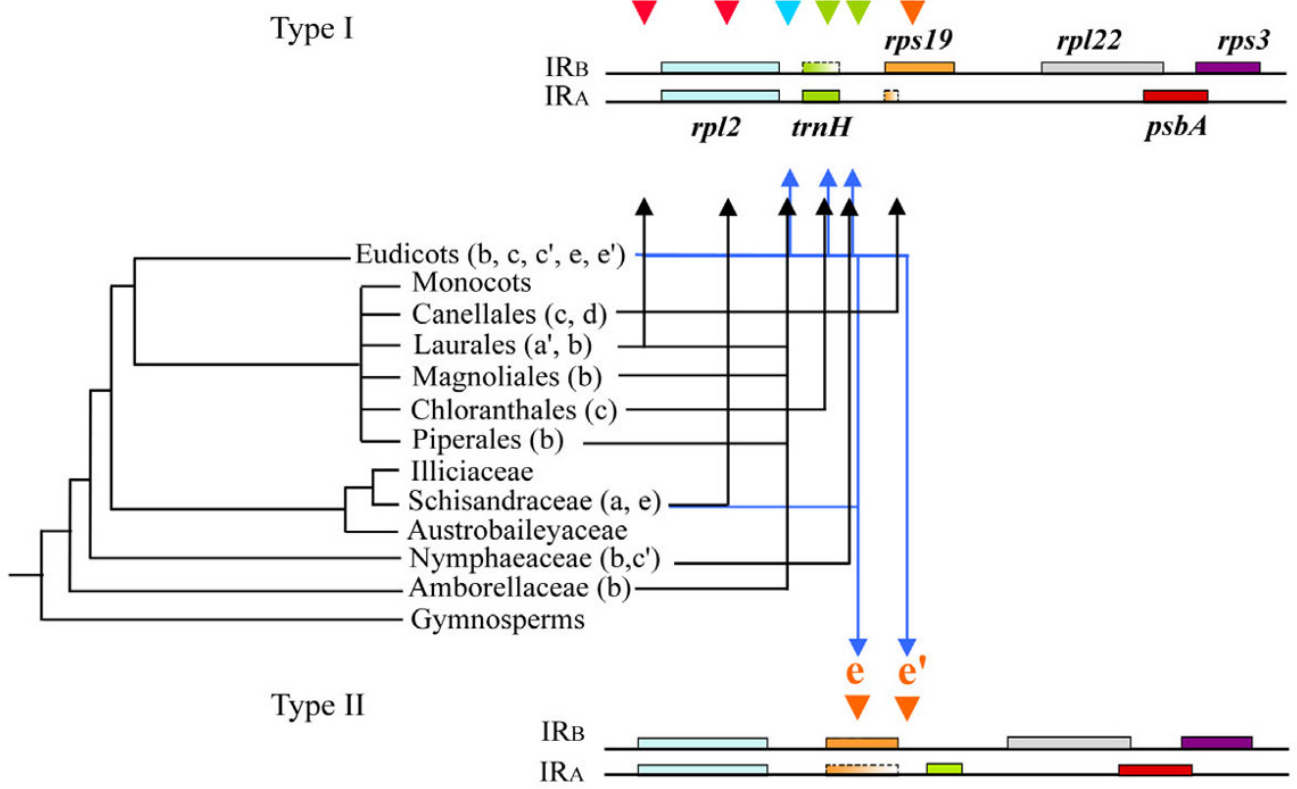

B Monocots

$\begin{array}{lllllll}\text { Type III } & \mathbf{b} & \mathrm{c}^{\prime} & \mathrm{d} & \mathbf{f} & \mathbf{g} \\ \nabla & \nabla & \boldsymbol{\nabla} & \boldsymbol{\nabla} & \boldsymbol{\nabla}\end{array}$

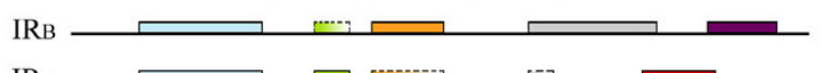

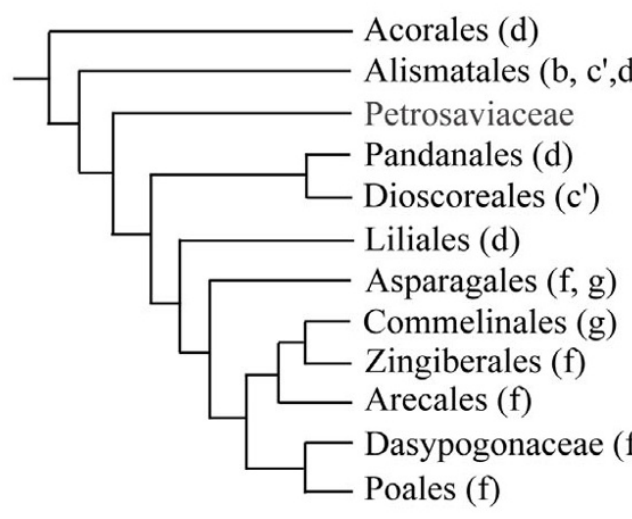

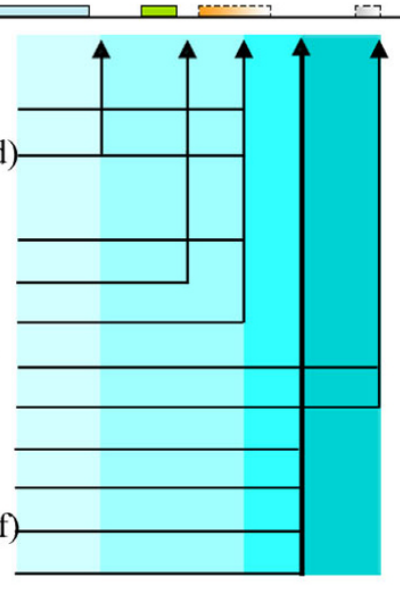

\section{Figure I}

Classification of IR-LSC junction types based on the organization of genes flanking $J_{L B}$ and $J_{L A}$ in angiosperms. Triangles coded by different colors and letters indicate various locations of IR-LSC junctions in corresponding angiosperm lineages. Shaded boxes denote protein-coding genes, and boxes with broken margins and gradient color stand for genes that are variable in length. Relationships of major non-monocot $(A)$ and monocot $(B)$ lineages followed the phylogenetic trees of Soltis et al. (2005) [27]. (A) In type I the IR-LSC junction is located downstream of $r p / 2$ and upstream of rps 19 . In type II rps /9 is located downstream of $r p / 2$ in $I R_{A}$. (B) In type III each IR has a copy of the trnH-rps 19 cluster, although in the $I R_{A}$ regions the $r p s / 9$ genes are variously truncated at the $3^{\prime}$ regions in sampled taxa. The blue gradient on the right side of the monocot phylogenetic tree denotes the progressively expanded IRs. 
(data shown in the additional file 1). In these cases, designated as type $\mathrm{I}$, an intact $\operatorname{trn} H$ gene is always present near the $\mathrm{J}_{\mathrm{LA}}$ but absent from the $\mathrm{J}_{\mathrm{LB}}$. In Chloranthus oldhami, $\mathrm{C}$. spicatus, Sarcandra glabra (Chloranthales), Canella winterana (Canellales), Ranunculus japonica and $R$. macranthus (eudicot), a partial $\operatorname{trnH}$ sequence is found extending to position $\mathrm{C}$ in $\mathrm{IR}_{\mathrm{B}}$ (Fig. 1A, additional file 1). The IR-LSC junctions were located upstream of position $c^{\prime}$ (i.e. upstream of trnH) in Nuphar advena (Nymphaeaceae) and Elaeagnus formosana (Elaeagnaceae, eudicot), at position a in Kadsura japonica (Schisandraceae, Austrobaileyales), and at position a' in Calycanthus fertilis and C. floridus (Calycanthaceae, Laurales, [29,30]) (Fig. 1A). However, Vitis vinifera (Vitaceae, eudicot) showed a complete loss of rpl2 near $\mathrm{J}_{\mathrm{LA}}[31]$.

The Winteraceae (Canellales), exemplified by Zygogynum pauciflorum and Drimys granadensis [29], were exceptional in that the organization of the genes flanking the IR-LSC junctions resembled the one found in most monocots, rather than the organization seen in other non-monocot angiosperms. Notably, each of their IRs contained a $\operatorname{trnH}$ rps19 cluster and their IR-LSC junctions were located within the 5 ' portion of $r p s 19$ (position d, Fig. 1).

Type II IR-LSC junctions were found in Schisandra arisanensis (Schisandraceae; Austrobaileyales) and some 41 representative eudicots (Fig. 1A; additional file 1). Unlike type I, the $\mathrm{J}_{\mathrm{LA}}$ of type II shifted to the $5^{\prime}$ end of the truncated $r p s 19$ in $\mathrm{IR}_{\mathrm{A}}$ (position e and $\mathrm{e}^{\prime}$, Fig. 1A, additional file 1).

\section{IRs of monocots generally contain trnH-rps I 9 clusters} In contrast to basal angiosperms and eudicots, most monocots (Fig. 1B) had trnH-rps19 clusters present in each of the two IRs, and the IR-LSC junctions were generally at position $\mathrm{f}$ (Arecales, Dasypogonaceae, Asparagus densiflorus [Liliales], Poales and Zingiberales) or g (in Asparagales and Commelinales) (Fig. 1B). This type of gene organization was classified as type III. In addition, IR-LSC junctions of some monocots were located downstream of $r p l 2$ (position b; in Araceae, most Alismataceae, and Hydrocharitaceae), of $\operatorname{trnH}$ (position c' in Potamogetonaceae and Dioscoreaceae), or within $r p s 19$ (position d, Fig. 1; in Acorales, Lilium formosamum [Liliales] and Panadanales). When the IR-LSC junction was at position $\mathrm{d}$, the rps19 sequence in $\mathrm{IR}_{\mathrm{A}}$ was found to be partially truncated most of the times.

\section{Sequences flanking IR-LSC junctions are more variable in monocots than in non-monocot angiosperms}

Figure 2 illustrates alignment of the sequences flanking the $\mathrm{J}_{\mathrm{LA}}$ regions in some representatives of basal angiosperms and eudicots (A) and monocots (B). Of particular interest is the observation that the IR-LSC junctions of basal angiosperms, eudicots and monocots are commonly found at either polyA tract or A-rich regions (Fig. 2 ). We also found that the dicot IR sequences near the IRLSC junctions varied little and could be aligned among orders having the same or different IR-LSC junction types, while in monocots the corresponding regions were very different and difficult to align across different orders (Fig. 2B). Moreover, within the sampled angiosperm families the sequences flanking the $\mathrm{J}_{\mathrm{LA}}$ regions were very similar.

\section{Transcription of monocot trnH-rps $I 9$ of $I R_{A}$ is regulated by both chloroplast $\mathrm{SIO}_{A}$ and psbA promoters}

Among the chloroplast operons, the $S 10$ ribosomal protein operon is the largest. It contains genes encoding both small $(r p s)$ and large $(r p l)$ ribosomal protein subunits that are organized into a polycistronic transcription unit conserved in known cpDNAs [32]. In angiosperms, the 5 ' end of the $S 10$ operon is initiated within the IR, but only in $I_{B}$ does the operon extend into the LSC region, and the S10 operon is only partially in $\mathrm{IR}_{\mathrm{A}}$ (viz. the $S 10_{A}$ operon). However, a second operon in $\mathrm{IR}_{\mathrm{A}^{\prime}}$ the $p s b A$ operon, is transcribed from LSC towards $\operatorname{IR}_{\mathrm{A}}$ [32] and opposite to the $S 10_{A}$ operon.

In the Winteraceae and a majority of monocots, the $\operatorname{trn} H$ rps19 cluster of $\mathrm{IR}_{\mathrm{A}}$ is included in both the $S 10$ and $p s b A$ operons. Therefore, this gene cluster may be regulated by two opposing promoters, the $S 10_{A}$ and the $p s b A$ (Fig. 3A). In monocots, if the $t r n H$ in $\mathrm{IR}_{\mathrm{A}}$ is indeed regulated by the above-mentioned two opposing promoters, the function of the $\operatorname{trn} H$ gene may be repressed because antisense-trn $H$ RNAs would be generated by both the $S 10_{A}$ and $S 10_{B}$ promoters. To verify this possibility, we conducted RT-PCR assays using specific primers for a type III representative, Asparagus densiflorus, with the IR-LSC junction located at position $\mathrm{f}$ (Fig. 1B).

Our results indicate that expression of the $\operatorname{trn} H$ gene in $\mathrm{IR}_{\mathrm{A}}$ is regulated by both the $S 10_{A}$ and $p s b A$ promoters. This suggests that the duplicated $\operatorname{trn} H$ gene located in the $\mathrm{IR}_{\mathrm{B}}$ region of most monocots and in some non-monocots has different fates (i.e. functional or degenerate in different lineages; see Fig. 1). Figure 3B shows that two RT-PCR products, a $250 \mathrm{bp}$ and a $700 \mathrm{bp}$ fragment, respectively, were generated when specific primer pairs for each were used (Fig. 3A). The former fragment was amplified from the transcripts made by the $p s b A$ promoter, and the latter by the $\mathrm{S} 10$ promoter. This result confirms that the $t r n H$ rps 19 cluster of $\mathrm{IR}_{\mathrm{A}}$ is regulated by two opposing promoters (Fig. 3B), indicating that the transcription machinery in IRs of monocots may differ from that of basal angiosperms and eudicots. 
A Basal Angiosperm, Magnoliids, and Eudicots

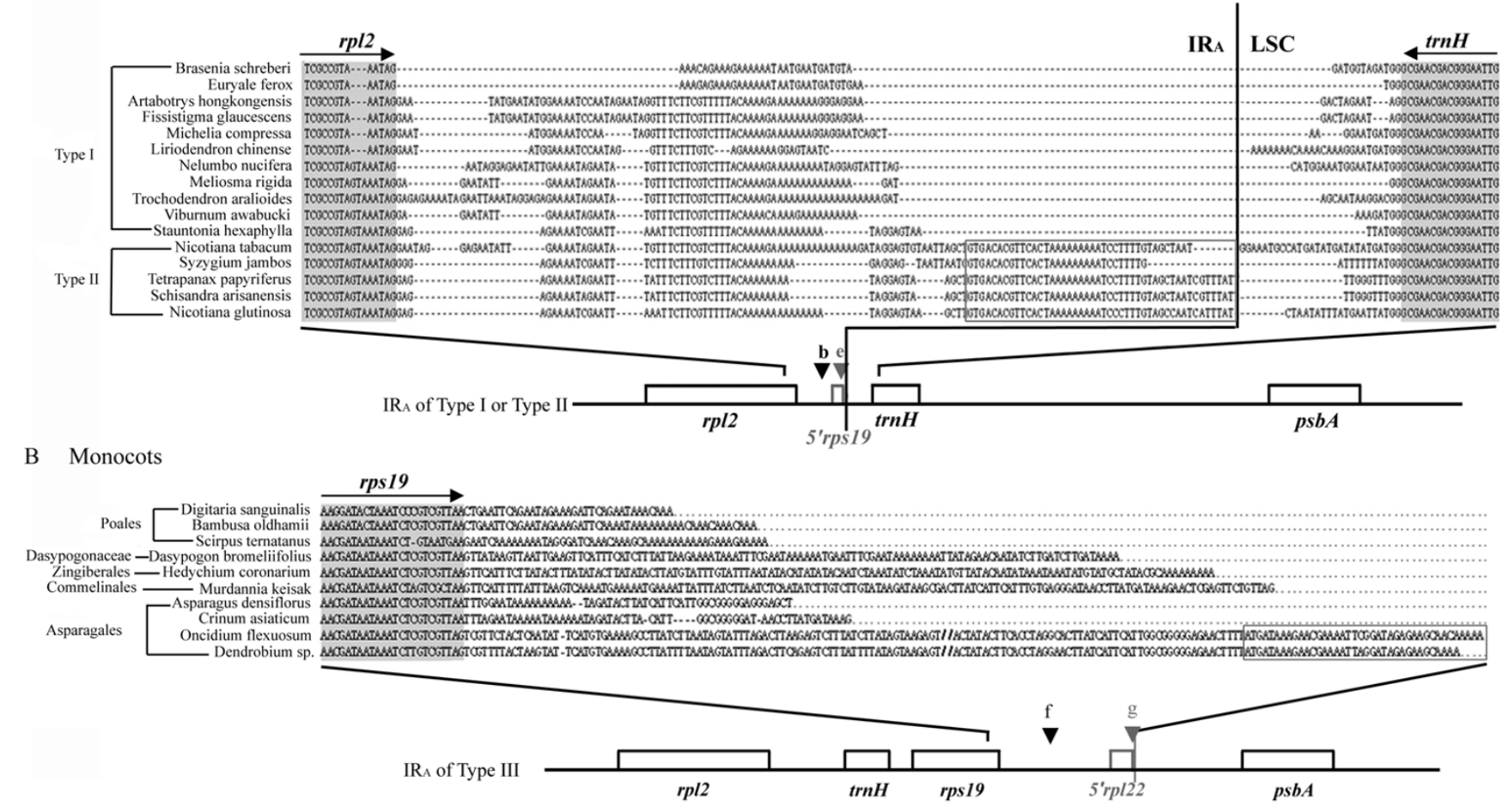

Figure 2

Alignment of sequences flanking J LA regions in some basal angiosperms, Magnoliids, and eudicots (type I at position b, and type II at position e), and the sequences within the $J_{\text {LA }}$ in some monocots (type III at position $\mathrm{f}$ or g). Dashed lines denote gaps. Grey segments and the arrow lines above indicate coding regions and transcriptional directions of specified genes, respectively. (A) Grey box denotes degenerate rps 19 genes (5' segment) found in the $I R_{A}$ of the type II (position e) pattern. (B) $A$ degenerate $r$ pl22 gene (boxed sequences) found in the IR $\mathrm{R}_{\mathrm{A}}$ of type III (position $\mathrm{g}$ ). "//" stands for abbreviated base pairs in the sequences of Oncidium and Dendrobium.

\section{Discussion \\ Two evolutionary hypotheses for the flux of IR-LSC junctions in monocots}

As shown in Figure 1A, IR-LSC junctions of the Amborella + Nymphaeales are mainly located at position b, but junctions of monocots are further expanded to encompass LSC genes and are located at positions for $\mathrm{g}$. Since the two IRs of monocots usually include the trnH-rps19 cluster (position $\mathrm{f}$ or $\mathrm{g}$, further downstream of $r p l 2$; Fig. 1B), we hypothesize that at least two duplication events are required to explain the expansion of IRs in monocots during the course of IR evolution from an Amborella-like ancestor to present-day monocots. If this hypothesis is correct, it is expected that an intermediate junction type could be traceable in the cpDNAs of some early divergent monocot lineages between the two duplication events.

Narayanan et al. [33] have recently presented a model of gene amplification in eukaryotes that argues strongly for the involvement of hairpin-capped DSBs in the initiation.
Based on this model and our observations, we propose two hypotheses to account for the evolution of IR expansions in monocots (Fig. 4). In hypothesis A, a DSB event (Fig. 4, red arrowhead in step 1) occurs first within the $I_{B}$ of an Amborella-like ancestor, and then the free 3 ' end of the broken strand is repaired against the homologous sequence in $\mathrm{IR}_{\mathrm{A}}$. The repaired sequence extends over the original IR-LSC junction and reaches the area downstream of trnH (Fig. 4, step 1), so that duplication of a $\operatorname{trnH}$ gene in the newly repaired $I_{B}$ is achieved. Similarly, a second DSB event occurs in $I R_{A}$ adjacent to the $I R_{A}$-LSC junction (Fig. 4, red arrowhead at step 2) so that duplication of rps19 at $\mathrm{IR}_{\mathrm{A}}$ can be initiated, and a trnH-rps19 cluster nearby $\mathrm{J}_{\mathrm{LB}}$ (Fig. 4, step 2) is created. The newly formed IRs might cover the trnH-rps19 cluster and extend further into the intergenic spacer between $r p s 19$ and $r p l 22$ (Fig. 4, step 1 to step 2). Furthermore, if one additional DSB event took place within the intergenic spacer located between rps19 and rpl22 in the LSC region, a partial rpl22 gene would be duplicated at $\mathrm{IR}_{\mathrm{A}} \mathrm{using}$ the $r p l 22$ sequence of 


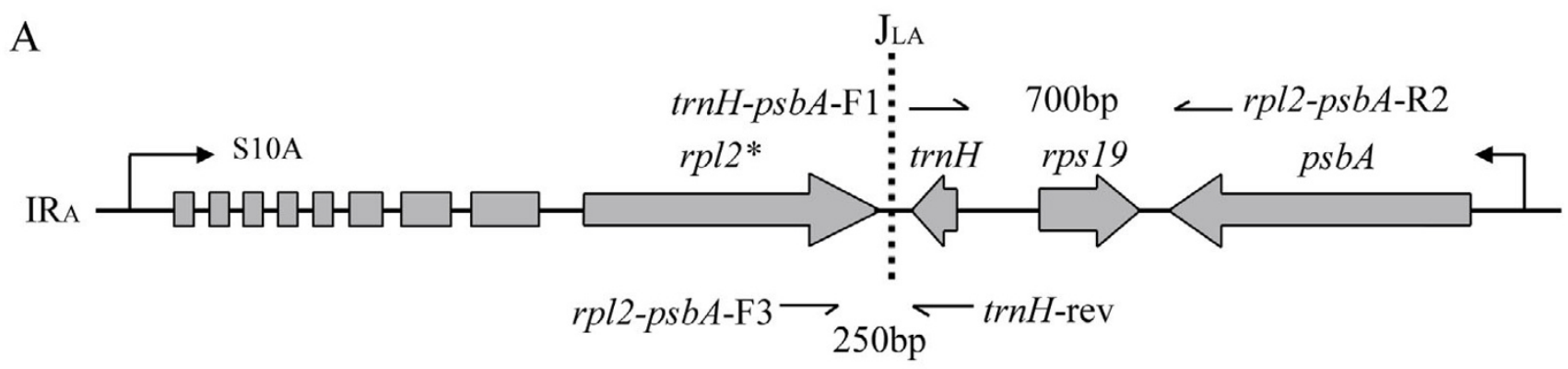

B

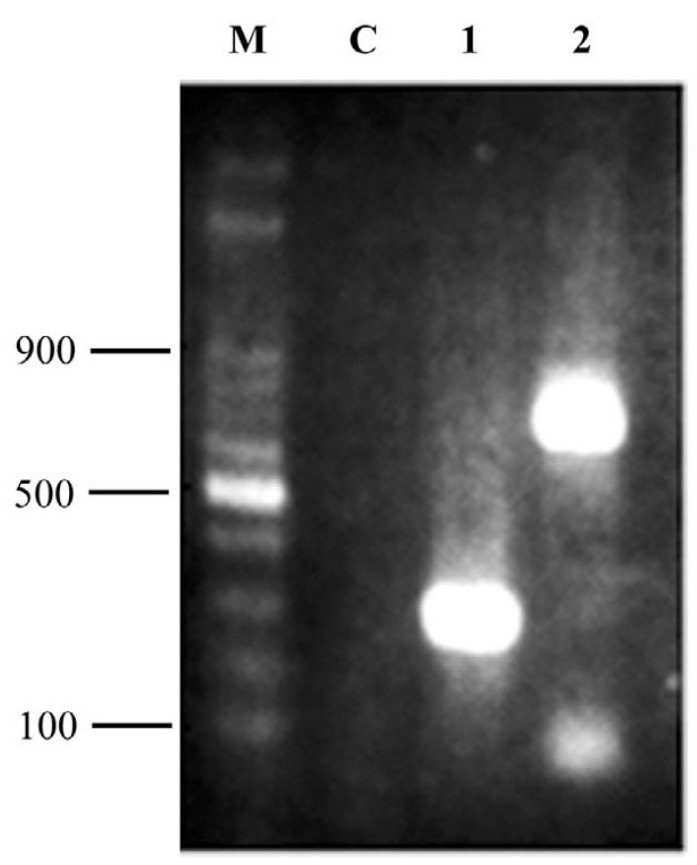

Figure 3

Transcription analysis of the $\mathrm{S} / 0$ and psbA operons in a monocot representative, Asparagus densiflorus. (A) The relative position of the SIO and psbA operons at the flanking region of the $I R_{A}-L S C$ junction. An arrow line denotes the transcriptional direction. One-side arrow lines indicate primers. (B) Transcripts obtained by reverse transcription PCR (RT-PCR). Lane M, I00 bP ladder; lane $C$, negative control using the same RNA as the template in lanes I and 2; lane I, RT-PCR with the primer pair trnHrev and rp/2-psbA-F3; lane 2, RT-PCR with the primer pair trnH-psbA-FI and rp/2-psbA-R2.

LSC as a template, and from then on the repaired IRs might have expanded towards the 5 ' region of the rpl22 (Fig. 4, step 2 to step 3). The exceptionally long IRs observed in the Orchidaceae and Commelinales are likely to have been generated by this process. The same outcomes could also result if the process proceeded directly from step 1 to step 3 without step 2 (Fig. 4, path indicated by green dashed arrow).
Hypothesis B, on the other hand, assumes that rps19 would be duplicated or converted prior to the duplication of $t r n H$ through a DSB event that takes place at $\mathrm{IR}_{\mathrm{A}}$ first (Fig. 4; blue arrowhead of step 1). A second DSB event (Fig. 4; blue arrowhead of step 2) then would take place within the $I_{B}$ region through a similar repair process to the one mentioned before, so that a duplicated $\operatorname{trnH}$ is generated at $I_{B}$. Finally, the IRs expand downstream of 
Amborella-like ancestor (Type I)
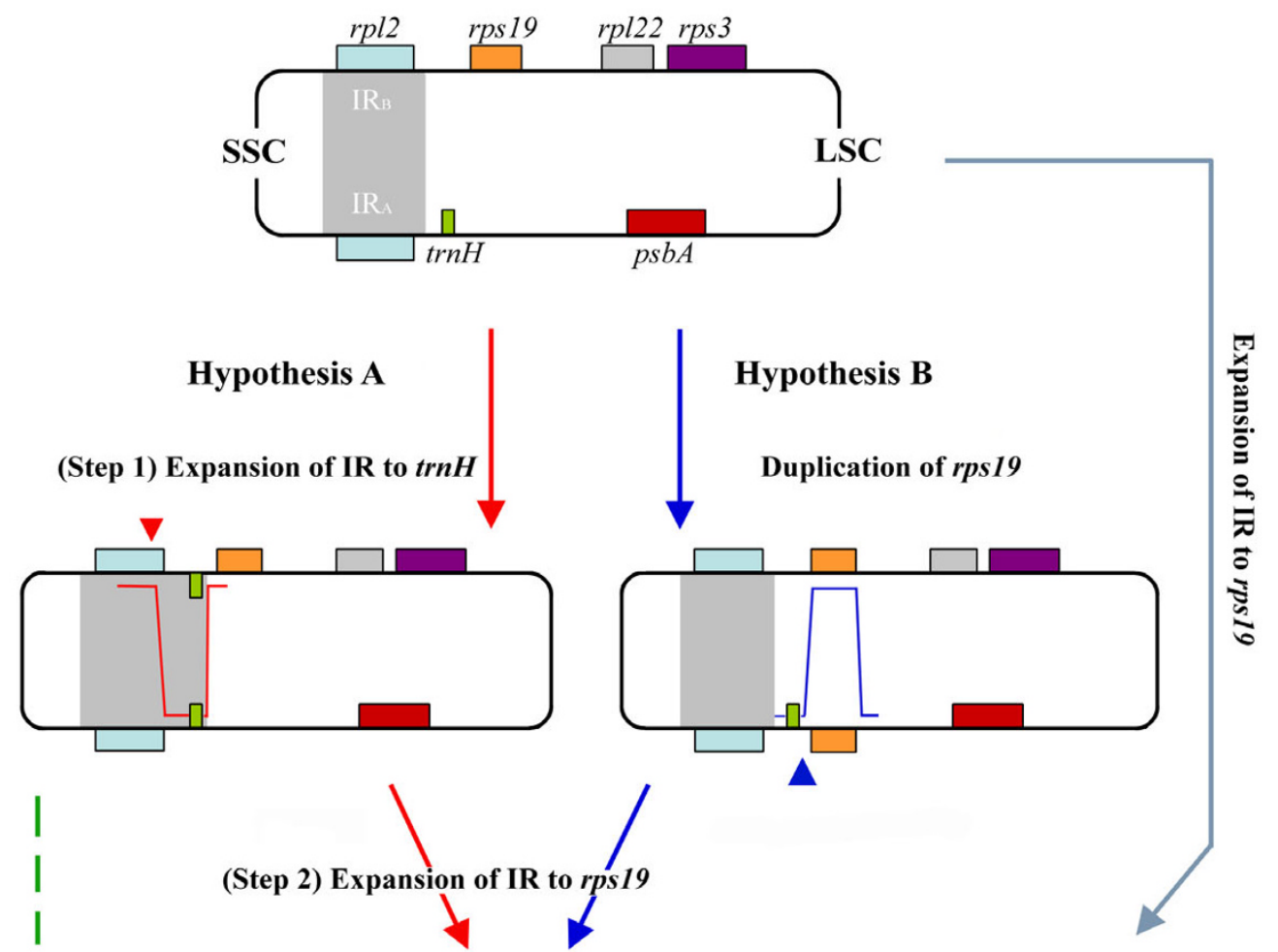

I Most monocots (Type III)

Eudicots only (Type II)

1
I
I
I
1
1
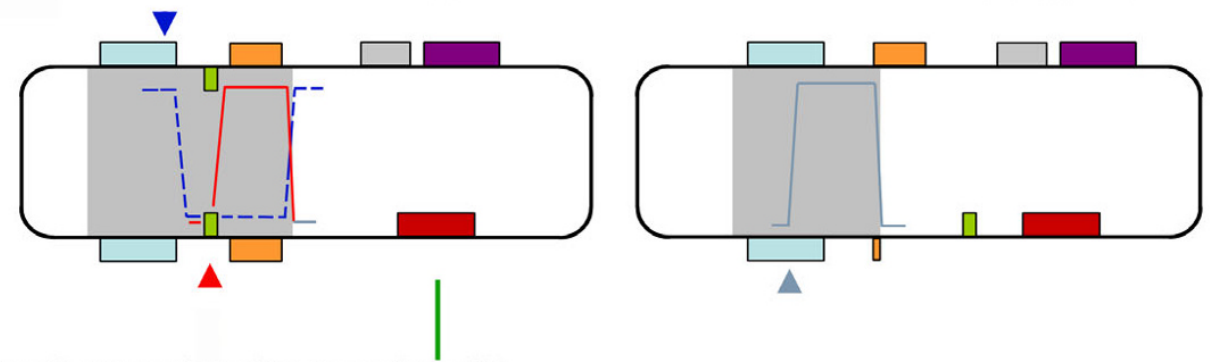

(Step 3) Expansion of IR to partial rpl22

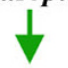

Orchidaceae and Commelinales (Type III)

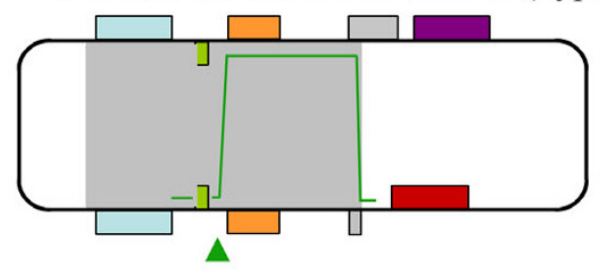

Figure 4

Two hypotheses for the evolutionary derivation of the trnH-rps 19 cluster in IRs of monocots from an Amborella-like ancestor. Arrow lines coded by different colors indicate distinct evolutionary pathways. Arrowheads denote possible breakpoints when DSB events occurred (different DSB colors are associated with different IR expansions). The light blue arrow line refers to a scenario in which a type II IR-LSC junction was established (see Fig. I) in some eudicots (note that the rps 9 residue is situated between $r p / 2$ and $t r n H$ in $I R_{A}$ ). The grey area in each cpDNA molecule highlights the IRs at all evolutionary stages. 
rps19. In hypothesis B subsequent extension of IRs is assumed to resemble step 3 of hypothesis $\mathrm{A}$.

Duplication of a partial or complete rps19 gene was also observed in some eudicots and Schisandraceae (type II) with their respective IR-LSC junctions located at position e or $e^{\prime}$ (additional file 1; Fig. 1). However, these duplicated rps19 genes (both partial and complete) are situated between the $r p l 2$ and $t r n H$ genes of the $\mathrm{IR}_{\mathrm{A}}$ (refer to type II in Fig. 1A and Fig. 4 [see the light blue line at the right side leading to eudicots]) rather than downstream of $\operatorname{trnH}$ or upstream of $p s b A$ (refer to step (2) and (3) of hypothesis $A$ in Figure 4). Therefore, the gene arrangement flanking the $I_{\mathrm{A}}$-LSC of type II deviates from that of type I, suggesting that duplication of $r p s 19$ genes in type II must have a distinct evolutionary history.

Based on comparisons of aligned rpl2-trnH and trnH-rps19 intergenic spacer sequences from representatives of major monocot orders (Figure 5A, B), it is apparent that these two spacer sequences are separately highly similar across the sampled monocot orders. These data give strong support to hypothesis A that in monocots expansion and inclusion of trnH-rps19 gene cluster in IRs might require at least two common DSBs (please refer to steps 1 to 3 of hypothesis $A$ in Figure 4): one occurring within $\operatorname{IR}_{B}$ (refer to Fig. 4, step 1 ), and the within $\operatorname{IR}_{\mathrm{A}}$ (refer to Fig, 4 step 2 or 3$)$.

However, we did not discover any inverted repeats that might have led to the formation of hairpins in the monocot intergenic spacers of trnH and rps19. Therefore, we are inclined to conclude that the expansions of monocot IRs took the path depicted in hypothesis A.

\section{IR expansion may be initiated by DSB and end in the nearby polyA region in angiosperms}

Goulding et al. [15] proposed two models to account for two kinds of IR expansion: (1) small and random IR expansions, caused by gene conversion (viz. single strand break); and (2) large IR expansions, like those found in the Nicotiana species, rice and maize, generated via DSB events. Narayanan et al. [33] further demonstrated that DSBs can trigger gene amplification through a variety of mechanisms, and that breakage at the inverted repeats of chromosomes can cause gene amplification.
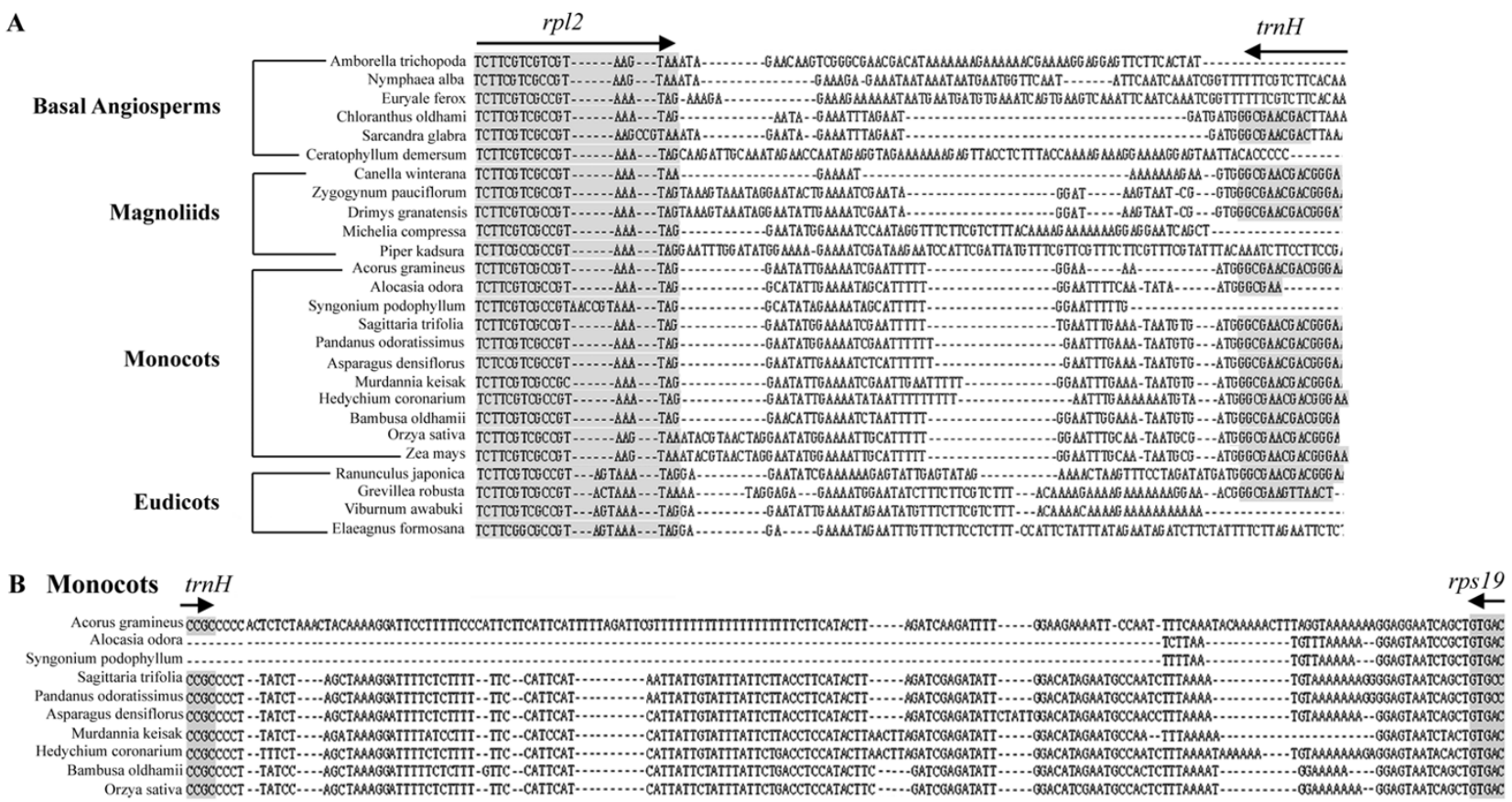

\section{Figure 5}

Comparisons of sequences that flank $J_{\text {LA }}$ regions in angiosperms. (A) Alignment of $r p / 2$-trnH intergenic spacers in representative basal angiosperms, magnoliids, monocots, and eudicots. Grey regions and the arrow lines above indicate locations and transcriptional directions of $r p / 2$ and $t r n H$, respectively. (B) Alignment of the $t r n H-r p s / 9$ intergenic spacer sequences at $I R_{A} s t r a n d$ among representatives of major monocot orders. Grey regions with arrow lines indicate locations and transcriptional directions of $\mathrm{trnH}$ and $\mathrm{rps} / 9$, respectively. 
After a critical comparison of genes or sequences adjacent to the IR-LSC junctions in 33 major orders and 8 families of angiosperms (following the classification system proposed by Soltis et al. 2005 [27]), we hypothesize that IR expansions resulted principally from the DSB events that occurred during IR evolution from the Amborella-like ancestor to monocots. This hypothesis is founded on the following 5 observations: (1) the length of IR expansion from basal angiosperms to monocots is large (more than $100 \mathrm{bp}$ ); (2) trnH and $r p s 19$ are situated downstream of $I_{A}$ and $I_{B}$, respectively, in all sampled basal angiosperms (Fig. 1A). This type of gene arrangement might represent the ancestral gene pattern in basal angiosperms; (3) IRs of several basal angiosperms (e.g. Schisandraceae, Chloranthales and Magnoliales, Winteraceae) and eudicots (Fig. 1A) have partially or completely duplicated trnH genes located at $\mathrm{IR}_{\mathrm{B}} ;(4)$ in comparison with other angiosperms, monocot IRs have expanded further to include a duplicated $r p s 19$ in $\mathrm{IR}_{\mathrm{A}^{\prime}}$ and this expansion should have occurred before the diversification of major monocot orders; and (5) the IRs of advanced monocots (from Asparagales to Poales) have expanded to encompass more LSC sequences or genes (Fig. 1B). Nevertheless, the latter expansions did not apparently result from another common DSB event but from independent ones, because among sampled monocot orders the downstream regions of rps19 genes have low sequence similarity (Fig. 2). At the infra-order level of angiosperms, gene conversion might occur frequently at meiosis and cause small IR expansion or contraction during evolution, as found in Apiaceae [14] and Nicotiana [15].

Studies on the IR-LSC junctions of Nicotiana species [15] and Apiaceous plants [14] have indicated that short repeats or "polyA tract" sequences associated with tRNAs at the IR-LSC boundaries might be likely hotspots for recombination. We also observed that polyA tract sequences are commonly present near the IR-LSC junctions in all the basal angiosperms, eudicots and monocots examined (Fig. 2), indicating that such sequences are closely linked with the dynamics of IR-LSC junctions and expansion of IRs. In this regard, we further propose that IR expansion may initiate at the DSBs and finish at the polyA tract regions, where recombination may actively occur, and that the recombination mechanism in cpDNA may resemble that reported for nuclear genomes by Narayanan et al. [33].

According to our hypothesis, DSBs within IRs must have been frequent during angiosperm evolution. However, only those which led to successful IR expansions, and have subsequently been retained in the extant taxa, are detectable. Based on our observations, it is evident that the type of IR-LSC junction appears to be informative, at least at the level of order, and is therefore useful for inferring phylogenetic relationships at this rank and above.

\section{Expansion of monocot IRs is correlated with the divergence pattern of monocot phylogeny}

As shown in Figure 1B, IR-LSC junctions of basal monocots including Acorales, Pandanales and Liliales are usually located at position $\mathrm{d}$. This type might represent a primitive state. In contrast, IR-LSC junctions of the derived monocots, such as Asparagales and Poales, have generally expanded to position $\mathrm{f}$ or $\mathrm{g}$. This trend in IR expansion seems to correlate well with the divergence pattern of monocot lineages in the multigene tree of Soltis et al. $[27,34]$, which shows Acorales to be a sister group to other monocots. This correlation connotes the ancient status of the order and the continuous IR expansion experienced by the more terminal and derived lineages, viz. Asparagales, Commelinales, Zingiberales, Arecales, Dasypogonaceae and Poales.

It is worth mentioning that in some monocots (e.g. Pandanales and Liliales) the IR-LSC junctions are located at position $\mathrm{d}$, with a truncated $r p s 19$ gene at $\mathrm{IR}_{\mathrm{A}}$. According to hypothesis A (Fig. 4), duplication of rps19 at $\mathrm{IR}_{\mathrm{A}}$ was due to a second DSB event in $\mathrm{IR}_{\mathrm{A}}$ (Fig. 4, red arrowhead at step 2), followed by a sequence repair supposed to have been terminated within or downstream of the rps19 gene. Duplication of the rps19 gene will lead to a shift of the IRLSC junction to position d or f (Fig. 1B). However, in Pandanales and Liliales, the rps 19 sequences of $\mathrm{IR}_{\mathrm{A}}$ are incomplete or degraded. We considered these common degradations likely to be secondary rather than primary, since the majority of monocot orders have the trnH-rps19 clusters (Fig. 1B). Moreover, among the major monocot orders (except Alismatales) the intergenic spacer sequences within the trnH-rps19 cluster (Fig. 5B) have a high degree of similarity, suggesting that among the sampled monocots a common DSB event might have taken place adjacent to the trnH gene. Therefore, the IRs in Acorales, Pandanales and Liliales are likely to have contracted, causing a shift of the IR-LSC junctions from around position $\mathrm{f}$ to position $\mathrm{d}$.

A comparison of the downstream non-coding or spacer sequences of the rps19 genes in monocots reveals that the sequences do not have a common origin (Fig. 2B), as they are highly variable and a reliable sequence alignment is impossible except between closely related con-ordinal taxa (e.g. Zingiberales and Asparagales). This indicates that these spacer sequences had diverse origins and are likely to have resulted from independent DSB events occurring at different points within the IRs.

In contrast, it appears that expansion of IR-LSC junctions did not parallel the evolutionary diversification of basal 
angiosperms and eudicot lineages (Fig. 1A). In type I (Fig 1), IR expansion downstream of rps19 is extremely rare in eudicots, with the exception of Adzuki bean (Perry et al. [18]) and a Pelargonium species (Palmer et al. [16], Chumley et al. [11]). According to our hypothesis A (Fig. 4), the scenario of IR expansion in these two eudicots may have different origins from those of monocots and other eudicots (i.e. type II, Fig. 1), with IRs that have expanded downstream of rps19 genes. Similarly, significant IR contractions in the basal angiosperm Illicium oligandrum (about $1 \mathrm{~kb})$, coriander (4 kb) [13,14], and Cuscuta reflexa (about $700 \mathrm{bp}$ to $8 \mathrm{~kb}$ ) [35] seem to be separate events in their respective lineages.

\section{Implications of sequences flanking IR-LSC junctions for angiosperm phylogeny}

In extant angiosperms, the relationships among the remaining 5 lineages (magnoliids, monocots, eudicots, Chloranthaceae and Ceratophyllum) are unresolved $[19,26,27]$. To what extent the dicot lineage is a sister group of monocots remains uncertain, probably a reflection of the rapid radiation and extinction of early angiosperms soon after they originated [36,37].

Recent phylogenetic analyses based on plastid sequence data have suggested that monocots and eudicots are sister taxa (Graham et al. [38] and Cai et al. [39]), but with low bootstrap support ( $67 \%$ and $72 \%$, respectively). In addition, several lines of evidence have indicated that Ceratophyllaceae could be the sister group of monocots [40-44].

Here we present an alternative view on this issue. As illustrated in Figure 1, an intact $t r n H$ is duplicated in $I_{B}$ of all monocots, one basal angiosperm (Nuphar advena, position c'), and two winteraceous magnoliid species (Zygogynum paucifolum and Drimys granadensis, position d) [29]. Sequence comparison revealed that only Winteraceae and monocots have highly similar spacer sequences between the $r p l 2$ and $t r n H$ genes (Fig. 5B), suggesting that duplication of trnH gene in $\mathrm{IR}_{\mathrm{B}}$ of the two taxa might be common or similar (viz. convergent). On the other hand, Acorales (the most basal lineage in monocots, [27]) has its IR endpoint at position $d$, suggesting that those lineages with IRLSC junctions at position b and c' (most Alismatales and Dioscoreales) might have resulted from separate, independent contractions. Our alternative view on the relationships among monocots and their relatives is preliminary, as it is only based on comparison of genic organizations at IR-LSC junctions. Additional molecular and morphological data are required to improve our understanding of monocot phylogeny.

\section{The presence of two anti-sense strands of trnH in monocot IRs is mysterious}

The presence of a trnH-rps19 cluster in the IRs appears to be a common feature in monocots other than some Alismatids (additional file 1, Fig. 1), in which IR-LSC junctions are located at position $b$ and strongly resemble those of most non-monocot angiosperms. However, alignment of the intergenic spacers between $r p l 2$ and $t r n H$ in some Alismatales (e.g. Alocasia odora) and other monocots, basal angiosperms and eudicots (Fig. 5) reveals that sequences of the Alismatids are more similar to other monocots than to non-monocot angiosperms. This implies that IR expansions in some Alismatids might share evolutionary scenarios similar to those proposed for other monocots, and that the short IRs (or IR contraction) in some other Alismatids are likely due to either an early termination of the repair-extension reaction after the first DSB in step 1 of hypothesis A (Fig. 4), or to a contraction after this step.

In monocots, each IR usually contains a trnH gene, while in most basal angiosperms and eudicots the gene is rarely present in $\mathrm{IR}_{\mathrm{B}}$ (see Fig. 1A: type I and type II). Why is the duplicated trn $H$ gene able to survive in $\mathrm{IR}_{\mathrm{B}}$ of most monocots but is absent, degraded or truncated in most nonmonocot angiosperms? In two studied eudicots, Lotus japonicus [18] and Spinacea oleracea [45], the transcriptional activity of $S 10_{A}$ dropped significantly because of either the high transcription levels of the $p s b A$ and $t r n H$ genes or the termination of $S 10_{A}$ proximal to $\mathrm{J}_{\mathrm{LA}}$ [32]. Therefore, in non-monocot angiosperms, trnH-encoded mRNA molecules constitute only one sense strand, transcribed solely by the $p s b A$ operon rather than by the $S 10_{A}$ operon. Because anti-sense RNA molecules may interfere with the normal function of the sense RNA molecules [32], in monocots the mechanism by which anti-sense trnH is regulated by two $S 10_{A}$ promoters is mysterious. Further study on the evolution and survival of the duplicated $\operatorname{trn} H$ gene in $\mathrm{IR}_{\mathrm{B}}$ of monocots is desirable.

\section{Conclusion}

Extensive comparisons of the genic organizations flanking the IR-LSC junctions in 123 diversified angiosperm lineages revealed that monocots and non-monocot angiosperms generally have different IR-LSC junction types. Notably, IRs expanded more progressively in monocots than in non-monocot angiosperms, with more LSC genes being converted into IRs. With the exceptions of Alismatales and a few Acorales, the monocot $I_{\mathrm{A}}$ regions either encompass a trnH-rps19 cluster or extend as far as the 5' portion of the rpl22 gene, which is typically situated at the LSC region in non-monocot angiosperms. Various expansions of IRs in monocots have resulted in corresponding fluxes of IR-LSC junctions. Our results further indicate that the IR expansions in angiosperms can be 
explained by initiation of a DSB event and ending at a polyA tract region.

We proposed two hypotheses to explain the evolutionary derivation of the trnH-rps 19 cluster in the IRs of monocots from an Amborella-like ancestor (Fig. 4). Hypothesis A proposes that a DSB event occurs first within the $\mathrm{IR}_{\mathrm{B}}$ of an Amborella-like ancestor, and then the free 3 ' end of the broken strand is repaired against the homologous sequence in $\mathrm{IR}_{\mathrm{A}}$. The repaired sequence extends and results in the duplication of a $\operatorname{trnH}$ gene in the newly repaired $I_{B}$. A subsequent DSB event may occur in $I_{A}$ so that the $r p s 19$ at $\mathrm{IR}_{\mathrm{A}}$ is duplicated, whereby a trnH-rps19 cluster is created. Hypothesis B assumes that rps19 is duplicated or converted before the duplication of $t r n H$ via a DSB event that occurs at $I_{\mathrm{A}}$.

It is worth noting that IR expansions in monocots appear to correlate well with the divergence pattern of monocot phylogeny. The present study highlights the use of sequences flanking the IR-LSC junctions to address the evolutionary dynamics of IRs from basal angiosperms to monocots. Taken together with the evidence from the IRLSC junctions, we conclude that (i) monocots may be closely related to the Winteraceae (magnoliids) than to other basal angiosperms or eudicots, (ii) the shorter IRs in Alismatids are probably due to either an early termination of repair-extension after the first DSB, or to a contraction after this step, and (iii) the duplicated $\operatorname{trnH}$ genes in the $\mathrm{IR}_{\mathrm{B}}$ of most monocots and non-monocot angiosperms have distinct fates, which are likely regulated by different expression levels of $S 10_{A}$ and $S 10_{B}$ promoters. Further study is needed to unravel the evolutionary significance or advantage of the presence of an additional $\mathrm{trnH}$ in monocot IRs, and of IR expansion in more recently diverged monocots.

\section{Methods}

\section{Plant materials and DNA preparation}

Species sampled in this study were listed in the additional file 1. Total cellular DNA was extracted using the method of Saghai-Maroof et al. [46]. The extracted DNAs were used directly for PCR amplification.

\section{PCR amplification}

Primer design was based on published sequence data for conserved regions flanking the IR-LSC junctions. The J $\mathrm{LA}_{\mathrm{L}}$ regions were amplified with the primer pair $r p l 2-p s b A-\mathrm{F} 3$ and $r p l 2-p s b A-\mathrm{R} 2$, which correspond to the $3^{\prime}$ end of $r p l 2$ and the 5 ' end of $p s b A$ respectively (Fig. 1). The $\mathrm{J}_{\mathrm{LB}}$ region was amplified using two forward primers, rps3-F1 and $r p s 3-\mathrm{F} 2$, that respectively pair with a reverse primer $r p s 3-$ $r p l 2-\mathrm{R} 2$. The sequences of these primers are listed in Table 1. Amplicons were cleaned using the Gel Extraction System (Viogene, Taipei) and cloned into a pGEM T-Easy vector (Promega, Fitchsburg). Plasmid DNAs were purified using the Plasmid DNA Miniprep System (Viogene) and sequenced on an ABI 3730 automated sequencer (Applied Biosystems, Foster City). For each species two independent PCR clones were sequenced. Sequence alignments were made using GeneDoc (Ver. 2.6.02.)

\section{Reverse Transcriptase-Polymerase Chain Reaction (RT- PCR) Assay}

To verify the transcription of trnH-rps 19 that flanks the $\operatorname{IR}_{\mathrm{A}}$ region, total RNAs were extracted and purified by RNeasy ${ }^{\otimes}$ Plant Mini Kit (Qiagen, Hilden). The resulting RNAs were reversely transcribed to synthesize cDNA with Superscript II reverse transcriptase (Invitrogen, Indianapolis) and a specific primer (either trnH-psbA-F1 or trnH-rev), according to the manufacturer's protocol. The two synthesized cDNAs were then used with the primer pair trnH-psbA-F1 and $r p l 2-p s b A-\mathrm{R} 2$ to amplify a $674 \mathrm{bp}$ fragment, and the primer pair $t r n H$-rev and $r p l 2-p s b A-F 3$ to amplify a $298 \mathrm{bp}$ fragment. Each of the two reactions was conducted under

Table I: Primers used for analyses of IR-LSC junctions and in RT-PCR

\begin{tabular}{|c|c|c|c|}
\hline Primer number & Name & Sequence & Application \\
\hline I & $r p / 2-p s b A-F I$ & 5'-GACCCTAATCGAAATGCRTMCATTTG-3' & $\mathbb{I R}_{\mathrm{A}}$ \\
\hline 2 & $r p / 2-p s b A-F 2$ & 5'-TAATTGGAGATACYATTKKTTCTGGTACA-3' & $\mathbb{I R}_{\mathrm{A}}$ \\
\hline 3 & rpl2-psbA-RI & 5'-ATGGCDTTCAAYYTRAAYGGMTTYAATTT-3' & $I_{A}^{A}$ \\
\hline 4 & $r p / 2-p s b A-R 2$ & 5'-CTTGGTATGGARGTMATGCAYGARCGTAA-3' & $I_{A}$ \\
\hline 5 & rps3-rp/2-FI & 5'-GYTAAYTCRATRRCYTTTTTCATTGC-3' & $\mathbb{I R}_{B}$ \\
\hline 6 & rps3-rp/2-F2 & 5'-AWABYYYKTTGGTTKTGMRAACCA AA-3' & $\mathrm{IR}_{\mathrm{B}}$ \\
\hline 7 & rps3-rpl2-RI & 5'-AATGGGAAATGCCСTACСTTTG-3' & $\mathrm{IR}_{\mathrm{B}}$ \\
\hline 8 & rps3-rp/2-R2 & 5'-GTAGTAAGAGGRGTRGTTATGAACCC-3' & $\mathbb{R}_{B}$ \\
\hline 9 & $r p / 22-\mathrm{FI}$ & 5'-TRRTTTATTCBGCAGCVGCAAATGC-3' & $I_{B}$ \\
\hline 10 & rps3-FI & 5'-ATAWATTCYGCAAGAATRTTAGG-3' & $\mathbb{R}_{B}$ \\
\hline 11 & rps3-F2 & 5'-AGTCKGAAACCRAGTGGATTT-3' & $I_{B}$ \\
\hline 12 & $r p / 2-p s b A-F 3$ & 5'-GGTAARCGYCCYGTAGTAAGAGG-3' & $I_{A}$ \\
\hline 13 & trnH-psbA-FI & 5'-GGCGAACGACGGGAATTGAAC-3' & $\mathbb{I R}_{\mathrm{A}}$ \\
\hline 14 & trnH-rev & 5'-GGATGTAGCCAAGTGGATCAAGG-3' & $I_{A}^{A}$ \\
\hline
\end{tabular}


the following conditions: $94^{\circ} \mathrm{C}$ for $5 \mathrm{~min}$, followed by 30 cycles of $94^{\circ} \mathrm{C}$ for $30 \mathrm{~s}, 55^{\circ} \mathrm{C}$ for $30 \mathrm{~s}$, and $72^{\circ} \mathrm{C}$ for $30 \mathrm{~s}$, and ending with an extension of $72^{\circ} \mathrm{C}$ for $10 \mathrm{~min}$.

\section{Abbreviations}

cPDNA, chloroplast genome; IR, inverted repeat; SSC, small single copy; LSC, large single copy; bp, base pair; $\mathrm{J}_{\mathrm{LA}}$ junction between LSC and $\mathrm{IR}_{\mathrm{A}} ; \mathrm{I}_{\mathrm{LB}}$, junction between LSC and $\mathrm{IR}_{\mathrm{B}}$; DSB, double-strand break; RT-PCR: reverse transcriptase-polymerase chain reaction.

\section{Authors' contributions}

SMC conceived the study. CLC, CLW, TMS and RJW carried out the sequence analysis, and CCC provided the unpublished orchid data. CLC and CLW prepared the sequence data and submitted it to GenBank. CLC prepared the figures. RJW, SMC, and CLC wrote the manuscript. All authors read and approved the final manuscript.

\section{Additional material}

\section{Additional file 1}

Studied taxa and their GenBank accession numbers, references and IRLSC junction positions. This table (Table S1) provides detailed information about the studied 123 taxa, including 12 basal angiosperms, 16 magnoliids, 62 eudicots, and 33 monocots, involved in the analysis.

Click here for file

[http://www.biomedcentral.com/content/supplementary/14712148-8-36-S1.PDF]

\section{Acknowledgements}

This work was supported by a research grant from the Research Center for Biodiversity, Academia Sinica, to SMC, and in part by a grant from Guangzhou Forestry Administration to RJW. We thank Yin-Long Qiu for providing DNA of some basal angiosperms, and the staff of the RBG Kew DNA Bank for some plant genomic DNA materials. We gratefully acknowledge the critical reading of the manuscript by Pablo Bolanos-Villegas and Yu-Ting Lai and the valuable comments by three anonymous reviewers.

\section{References}

I. Kolodner R, Tewari KK: Inverted repeats in chloroplast DNA from higher plants. Proc Natl Acad Sci USA 1979, 76:4|-45.

2. Palmer JD: Comparative organization of chloroplast genomes. Annu Rev Genet 1985, 19:325-354.

3. Shinozaki K, Ohme M, Tanaka M, Wakasugi T, Hayashida N, Matsubayashi T, Zaita N, Chunwongse J, Obokata J, Yamaguchi-Shinozaki K, Ohto C, Torazawa K, Meng BY, Sugita M, Deno H, Kamogashira T, Yamada K, Kusuda J, Takaiwa F, Kato A, Tohdoh N, Shimada H, Sugiura $M$ : The complete nucleotide sequence of the tobacco chloroplast genome: its gene organization and expression. EMBO J 1986, 5:2043-2049.

4. Sugiura M: The chloroplast chromosomes in land plants. Annu Rev Cell Biol 1989, 5:51-70.

5. Kanno A, Hirai A: A transcription map of the chloroplast genome from rice(Oryza sativa). Curr Genet 1993, 23:166-I74.

6. Palmer JD, Osorio B, Thompson WF: Evolutionary significance of inversionsin legume chloroplast DNAs. Curr Genet 1988, | 4:65-74.
7. Woodbury NW, Roberts LL, Palmer JD, Thompson WF: A transcription map of the pea chloroplast genome. Curr Genet 1988, I 4:75-89.

8. Raubeson LA, Jansen RK: Chloroplast genomes of plants. In Plant diversity and evolution: genotypic and phenotypic variation in higher plants Edited by: Henry RJ. Wallingford: CABI Publishing; 2005:45-68.

9. Maier RM, Neckermann K, Igloi GL, Kössel H: Complete sequence of the maize chloroplast genome: gene content, hotspots of divergence and fine tuning of genetic information by transcript editing. J Mol Biol 1995, 25 I:6|4-628.

10. Sugiura M: The chloroplast genome. Plt Mol Biol 1992, 19:149-168.

II. Chumley TW, Palmer JD, Mower JP, Fourcade HM, Calie PJ, Boore JL, Jansen RK: The complete chloroplast genome sequence of Pelargonium $X$ hortorum: organization and evolution of the largest and most highly rearranged chloroplast genome of land plants. Mol Biol Evol 2006, 23:2 I75-2190.

12. Palmer JD, Stein DB: Conservation of chloroplast genome structure among vascular plants. Curr Genet 1986, 10:823-833.

13. Hansen DR, Dastidar SG, Cai Z, Penaflor C, Kuehl JV, Boore JL, Jansen RK: Phylogenetic and evolutionary implications of complete chloroplast genome sequences of four earlydiverging angiosperms: Buxus (Buxaceae), Chloranthus (Chloranthaceae), Dioscorea(Dioscoreaceae), and Illicium (Schisandraceae). Mol Phylogenet Evol 2007, 45:547-563.

14. Plunkett GM, Downie SR: Expansion and contraction of the chloroplast inverted repeat in Apiaceae subfamily Apioideae. Syst Bot 2000, 25:648-667.

15. Goulding SE, Olmstead RG, Morden CW, Wolfe KH: Ebb and flow of the chloroplast inverted repeat. Mol Gen Genet 1996, 252:195-206.

16. Palmer JD, Nugent JM, Herbon LA: Unusual structure of geranium chloroplast DNA: a triple-sized inverted repeat, extensive gene duplications, multiple inversions, and two repeat families. Proc Natl Acad Sci USA 1987, 84:769-773.

17. Aii J, Kishima Y, Mikami T, Adachi T: Expansion of the IR in the chloroplast genomes of buckwheat species is due to incorporation of an SSC sequence that could be mediated by an inversion. Curr Genet 1997, 3 I:276-279.

18. Perry AS, Brennan S, Murphy DJ, Kavanagh TA, Wolfe KH: Evolutionary re-organisation of a large operon in Adzuki bean chloroplast DNA caused by inverted repeat movement. DNA Res 2002, 9:157-162.

19. APGII: An update of the angiosperm phylogeny group classification for the orders and families of flowering plants: APG II. Bot J Linn Soc 2003, I 41:399-436.

20. Chang C-C, Lin H-C, Lin I-P, Chow T-Y, Chen H-H, Chen W-H, Cheng C-H, Lin C-Y, Liu S-M, Chang C-C, Chaw S-M: The chloroplast genome of Phalaenopsis aphrodite (Orchidaceae): comparative analysis of evolutionary rate with that of grasses and its phylogenetic implications. Mol Biol Evol 2006, 23:279-29I.

21. Leebens-Mack J, Raubeson LA, Cui LY, Kuehl JV, Fourcade MH, Chumley TW, Boore JL, Jansen RK, dePamphilis CW: Identifying the basal angiosperm node in chloroplast genome phylogenies: sampling one's way out of the Felsenstein zone. Mol Biol Evol 2005, 22:1948-1963.

22. Mathews S, Donoghue MJ: The root of angiosperm phylogeny inferred from duplicate phytochrome genes. Science 1999 , 286:947-950.

23. Qiu YL, Dombrovska O, Lee J, Li L, Whitlock BA, Bernasconi-Quadroni F, Rest JS, Davis CC, Borsch T, Hilu KW, Renner SS, Soltis DE, Soltis PS, Zanis MJ, Cannone J], Gutell RR, Powell M, Savolainen V, Chatrou LW, Chase MW: Phylogenetic analyses of basal angiosperms based on nine plastid, mitochondrial, and nuclear genes. Int J Plt Sci 2005, I 66:815-842.

24. Savolainen V, Chase MW, Hoot SB, Morton CM, Soltis DE, Bayer C, Fay MF, de Bruijn AY, Sullivan S, Qiu YL: Phylogenetics of flowering plants based on combined analysis of plastid atp $B$ and rbcL gene sequences. Syst Biol 2000, 49:306-362.

25. Soltis DE, Soltis PS: Amborella not a "basal angiosperm"? not so fast. Amer J Bot 2004, 91 :997-1001.

26. Qiu YL, Li L, Hendry TA, Li R, Taylor DW, Issa MJ, Ronen AJ, Vekaria $M L$, White AM: Reconstructing the basal angiosperm phylogeny: evaluation information content of mitochondrial genes. Taxon 2006, 55:837-856. 
27. Soltis DS, Soltis PS, Chase MW: Phylogeny and evolution of angiosperms Sunderland, MA: Sinauer Associates, Inc; 2005.

28. Kim Y-D, Jansen RK: Characterization and phylogenetic distribution of a chloroplast DNA rearrangement in the Berberidaceae. Plt Syst Evol 1994, 193:107-I I4.

29. Goremykin V, Hirsch-Ernst KI, Wölfl S, Hellwig FH: Analysis of the Amborella trichopoda chloroplast genome sequence suggests that Amborella is not a basal angiosperm. Mol Biol Evol 2003, 20:1499-1505

30. Goremykin V, Hirsch-Ernst KI, Wölfl S, Hellwig FH: The chloroplast genome of the "basal" angiosperm Calycanthus fertilis structural and phylogenetic analyses. Plant Syst Evol 2003 , 242: I |9- I35.

31. Jansen RK, Kaittanis C, Saski C, Lee S-B, Tomkins J, Alverson AJ, Daniell H: Phylogenetic analyses of Vitis (Vitaceae) based on complete chloroplast genome sequences: effects of taxon sampling and phylogenetic methods on resolving relationships among rosids. BMC Evol Biol 2006, 6:32.

32. Tonkyn JC, Gruissem W: Differential expression of the partially duplicated chloroplast SIO ribosomal protein operon. Mol Gen Genet 1993, 241:141-152.

33. Narayanan V, Mieczkowski PA, Kim H-M, Petes TD, Lobachev KS: The pattern of gene amplification is determined by the chromosomal location of hairpin-capped breaks. Cell 2006, 125: I283-1296.

34. Soltis PS, Soltis DE, Chase MW: Angiosperm phylogeny inferred from multiple genes as a tool for comparative biology. Nature 1999, 402:402-404.

35. Bömmer D, Haberhausen $G$, Zetsche $K$ : A large deletion in the plastid DNA of the holoparasitic flowering plant Cuscuta reflexa concerning two ribosomal proteins ( $r p / 2, r p / 23)$, one transfer RNA (trnl) and an ORF 2280 homologue. Curr Genet 1993, 24(I-2): $171-176$

36. Friis E, Pedersen K, Crane PR: Reproductive structure and organization of basal angiosperms from the early Cretaceous (Barremian or Aptian) of western Portugal. Int J Plt Sci 2000, 161:SI69-S182.

37. Friis EM, Pedersen KR, Crane PR: Early angiosperm diversification: the diversity of pollen associated with angiosperm reproductive structures in early Cretaceous floras from Portugal. Ann Missouri Bot Gard 1999, 86:259-296.

38. Graham SW, Zgurski JM, McPherson MA, Cherniawsky DM, M. SJ, Horne ESC, Smith SY, Wong WA, O'Brien HE, Biron VL, Pires JC, Olmstead RG, Chase MW, Rai HS: Robust inference of monocot deep phylogeny using an expanded multigene plastid data set. In Monocots: comparative biology and evolution Volume I. Edited by: Columbus JT, Friar EA, Hamilton CW, Porter JM, Prince LM, Simpson MG. Claremont: Rancho Santa Ana Botanic Garden; 2006:3-20.

39. Cai Z, Penaflor C, Kuehl JV, Leebens-Mack J, Carlson JE, dePamphilis $\mathrm{CW}$, Boore JL, Jansen RK: Complete plastid genome sequences of Drimys, Liriodendron, and Piper: implications for the phylogenetic relationships of magnoliids. BMC Evol Biol 2006, 6:77.

40. Qiu YL, Lee J, Bernasconi-Quadroni F, Soltis DE, Soltis PS, Zanis M, Zimmer EA, Chen ZD, Savolainen V, Chase MW: Phylogeny of basal angiosperms: analyses of five genes from three genomes. Int J PIt Sci 2000, 161:S3-S27.

4I. Qiu YL, Lee J, Bernasconi-Quadroni F, Soltis DE, Soltis PS, Zanis M, Zimmer EA, Chen Z, Savolainent V, Chase MW: The earliest angiosperms: evidence from mitochondrial, plastid and nuclear genomes. Nature 1999, 402:404-407.

42. Soltis DE, Soltis PS, Chase MW, Mort ME, Albach DC, Zanis M, Savolainen V, Hahn WH, Hoot SB, Fay MF, Axtell M, Swensen SM, Prince LM, Kress WJ, Nixon KC, Farris JS: Angiosperm phylogeny inferred from I 8S rDNA, rbcL, and atpB sequences. Bot J Linn Soc 2000, 133:38|-46|.

43. Zanis M, Soltis DE, Soltis PS, Mathews S, Donoghue MJ: The root of the angiosperms revisited. Proc Natl Acad Sci USA 2002, 99:6848-6853

44. Zanis MJ, Soltis PS, Qiu YL, Zimmer E, Soltis DE: Phylogenetic analyses and perianth evolution in basal angiosperms. Ann Missour Bot Gard 2003, 90: 129-150.

45. Zurawski G, Bottomley W, Whitfeld PR: Junctions of the large single copy region and the inverted repeats in Spinacia oleracea and Nicotiana debneyi chloroplast DNA: sequence of the genes for tRNA ${ }^{\text {His }}$ and the ribosomal proteins $S 19$ and $L 2$. Nucl Acid Res 1984, I 2(16):6547-6558.
46. Saghai-Maroof MA, Soliman KM, Jorgensen RA, Allard RW: Ribosomal DNA spacer-length polymorphisms in barley: Mendelian inheritance, chromosomal location and population dynamics. Proc Natl Acad Sci USA 1984, 8 I:80 I4-80 I8.

47. Goremykin VV, Hirsch-Ernst KI, Wölfl S, Hellwig FH: The chloroplast genome of Nymphaea alba: whole-genome analyses and the problem of identifying the most basal angiosperm. Mol Biol Evol 2004, 21 : | $445-1454$.

48. Raubeson LA, Peery R, Chumley TW, Dziubek C, Fourcade HM, Boore JL, Jansen RK: Comparative chloroplast genomics: analyses including new sequences from the angiosperms Nuphar advena and Ranunculus macranthus. BMC Genomics 2007, 8:174.

49. Moore MJ, Bell CD, Soltis PS, Soltis DE: Using plastid genomescale data to resolve enigmatic relationships among basal angiosperms. Proc Natl Acad Sci USA 2007, 104: 19363-19368.

50. Moore MJ, Dhingra A, Soltis PS, Shaw R, Farmerie WG, Folta KM, Soltis DE: Rapid and accurate pyrosequencing of angiosperm plastid genomes. BMC Plt Biol 2006, 6:17.

51. Schmitz-Linneweber C, Maier RM, Alcaraz J-P, Cottet A, Herrmann RG, Mache R: The plastid chromosome of spinach (Spinacia oleracea): complete nucleotide sequence and gene organization. Plant Mol Biol 200I, 45(3):307-3I5.

52. Kim K-J, Lee HL: Complete chloroplast genome sequences from Korean ginseng (Panax schinseng Nees) and comparative analysis of sequence evolution among 17 vascular plants. DNA Res 2004, I I:247-26I.

53. Ruhlman T, Lee S-B, Jansen RK, Hostetler JB, Tallon LJ, Town CD, Daniell $\mathrm{H}$ : Complete plastid genome sequence of Daucus carota: implications for biotechnology and phylogeny of angiosperms. BMC Genomics 2006, 7:222.

54. Samson N, Bausher MG, Lee S-B, Jansen RK, Daniell H: The complete nucleotide sequence of the coffee (Coffea arabica L.) chloroplast genome: organization and implications for biotechnology and phylogenetic relationships amongst angiosperms. Plant Biotechnology Journal 2007, 5:339-353.

55. Wolfe KH, Morden CW, Palmer JD: Function and evolution of a minimal plastid genome from a nonphotosynthetic parasitic plant. Proc Natl Acad Sci USA 1992, 89: I0648-10652.

56. Lee H-L, Jansen RK, Chumley TW, Kim K-J: Gene relocations within chloroplast genomes of Jasminum and Menodora (Oleaceae) are due to multiple, overlapping inversions. Mol Biol Evol 2007, 24: I161-II80.

57. Schmitz-Linneweber C, Regel R, Du TG, Hupfer H, Herrmann RG, Maier RM: The plastid chromosome of Atropa belladonna and its comparison with that of Nicotiana tabacum: the role of RNA editing in generating divergence in the process of plant speciation. Mol Biol Evol 2002, 19:1602-1612.

58. Yukawa M, Tsudzuki T, Sugiura M: The chloroplast genome of Nicotiana sylvestris and Nicotiana tomentosiformis: complete sequencing confirms that the Nicotiana sylvestris progenitor is the maternal genome donor of Nicotiana tabacum. Mol Genet Genomics 2006, 275:367-373.

59. Aldrich J, Cherney BW, Williams C, Merlin E: Sequence analysis of the junction of the large single copy region and the large inverted repeat in the petunia chloroplast genome. Curr Genet 1988, 14:487-492.

60. Kahlau S, Aspinall S, Gray JC, Bock R: Sequence of the tomato chloroplast DNA and evolutionary comparison of solanaceous plastid genomes. J Mol Evol 2006, 63:194-207.

6I. Hupfer H, Swiatek M, Hornung S, Herrmann RG, Maier RM, Chiu WL, Sear B: Complete nucleotide sequence of the Oenothera elato plastid chromosome, representing plastome I of the five distinguishable euoenothera plastomes. Mol Gen Genet 2000, 263:58I-585.

62. Steane DA, Jones RC, Vaillancourt RE: A set of chloroplast microsatellite primers for Eucalyptus (Myrtaceae). Mol Ecol Notes 2005, 5:538-54I.

63. Sato S, Nakamura Y, Kaneko T, Asamizu E, Tabata S: Complete structure of the chloroplast genome of Arabidopsis thaliana. DNA Res 1999, 6:283-290.

64. Nickelsen J, Link G: Nucleotide sequence of the mustard chloroplast genes trnH and rps 19'. Nucleic Acids Res 1990, 18: I05।.

65. Bausher MG, Singh ND, Lee S-B, Jansen RK, Daniell H: The complete chloroplast genome sequence of Citrus sinensis (L.) Osbeck var 'Ridge Pineapple': organization and phylogenetic relationships to other angiosperms. BMC Plt Biol 2006, 6:2I. 
66. Ibrahim RIH, Azuma J-I, Sakamoto M: Complete nucleotide sequence of the cotton (Gossypium barbadense L.) chloroplast genome with a comparative analysis of sequences among 9 dicot plants. Genes Genet Syst 2006, 8 I:3II-32I.

67. Lee SB, Kaittanis C, Jansen RK, Hostetler JB, Tallon LJ, Town CD, Daniell $H$ : The complete chloroplast genome sequence of Gossypium hirsutum: organization and phylogenetic relationships to other angiosperms. BMC Genomics 2006, 7:61.

68. Spielmann A, Roux E, von Allmen J-M, Stutz E: The soybean chloroplast genome: complete sequence of the rps/9 gene, including flanking parts containing exon 2 or $r p / 2$ (upstream), but lacking rp/22 (downstream). Nucl Acids Res 1988, 16:1199.

69. Saski C, S-B L, Daniell H, Wood TC, Tomkins J, Kim HG, Jansen RK: Complete chloroplast genome sequence of Glycine max and comparative analyses with other legume genomes. Plt Mol Biol 2005, 59(2):309-322.

70. Kato T, Kaneko T, Sato S, Nakamura Y, Tabata S: Complete structure of the chloroplast genome of a legume, Lotus japonicus. DNA Res 2000, 7:323-330

7I. Ravi V, Khurana JP, Tyagi AK, Khurana P: The chloroplast genome of mulberry: complete nucleotide sequence, gene organization and comparative analysis. Tree Genet Genomes 2006, 3:49-59.

72. Goremykin VV, Holland B, Hirsch-Ernst KI, Hellwig FH: Analysis of Acorus calamus chloroplast genome and its phylogenetic implications. Mol Biol Evol 2005, 22: 1813-1822.

73. Masooda MS, Nishikawaa T, Fukuokaa S-I, Njengaa PK, Tsudzukib T, Kadowakia K-l: The complete nucleotide sequence of wild rice (Oryza nivara) chloroplast genome: first genome wide comparative sequence analysis of wild and cultivated rice. Gene 2004, 340:133-139.

74. Hiratsuka J, Shimada $H$, Whittier R, Ishibashi T, Sakamoto M, Mori M, Kondo C, Honji Y, Sun C-R, Meng B-Y, Li Y-Q, Kanno A, Nishizawa $Y$, Hirai A, Shinozaki K, Sugiura M: The complete sequence of the rice (Oryza sativa) chloroplast genome: intermolecular recombination between distinct tRNA genes accounts for a major plastid DNA inversion during the evolution of the cereals. Mol Gen Genet 1989, 217:185-194.

75. Asano T, Tsudzuki T, Takahashi S, Smimada H, Kadowaki K: Complete nucleotide sequence of the sugarcane (Saccharum officinarum) chloroplast genome: a comparative analysis of four monocot chloroplast genomes. DNA Res 2004, I I:93-99.

76. Ogihara $Y$, Isono K, Kojima T, Endo A, Hanaoka M, Shiina T, Terachi T, Utsugi S, Murata M, Mori N, Takumi S, Ikeo K, Gojobori T, Murai R, Murai K, Matsuoka Y, Ohnishi Y, Tajiri H, Tsunewaki K: Structural features of a wheat plastome as revealed by complete sequencing of chloroplast DNA. Mol Genet Genomics 2002, 266:740-746.

\section{Publish with Bio Med Central and every scientist can read your work free of charge}

"BioMed Central will be the most significant development for disseminating the results of biomedical research in our lifetime. "

Sir Paul Nurse, Cancer Research UK

Your research papers will be:

- available free of charge to the entire biomedical community

- peer reviewed and published immediately upon acceptance

- cited in PubMed and archived on PubMed Central

- yours - you keep the copyright
BioMedcentral 